\title{
HINDRANCES AND SUGGESTIONS FOR SUSTAINABLE DEVELOPMENT OF LITHUANIAN COASTAL STRIP (ZONE)
}

\author{
EDUARDAS SPIRIAJEVAS ${ }^{1}$
}

Klaipėda University (Lithuania)

\begin{abstract}
In this article there are being analyzed the natural and social economic structures of Lithuanian coastal strip. The research is based on survey about the hindrances and proposed suggestions for sustainable development. There are presented authors' results about geographic profile of Lithuania's coastal region, degree of exploitation and processes of spatial planning, suggestions for improvement of sustainable development of coastal strip. There are distinguished the types of bad examples as institutional, projects related, shortage of financial issues, private housing and the types of good examples as legislative, institutional, projects related, NGOs related for exploitation and sustainable development of coastal strip.

KEY WORDS: sustainable development, Lithuania, coastal strip (zone).
\end{abstract}

JEL CODES: Q01, Q20, Q56, R11, Y10, Y91.

\section{Introduction}

The researches of coastal strips (zones) and coastal regions is a topic of high importance among the countries of the Baltic Sea region. The master plans of coastal areas indicate the principles and recommendations for sustainable development in theory and practice. Particularly, the issue of sustainability always is a topic of discussions in territorial planning, regional formation and development studies. Due to that fact, there are appearing the contradictions between public and private interests. The visibility of them is obviously seen in natural, social economic environment of the coastal strips, areas, regions. The coastal strips are indicators like that show the efficiency of legislative system of the country, implementing the principles of sustainability and decisions of territorial planning, deficiencies of planning actions and positive solutions as the outcomes.

The survey of Lithuanian coastal strip has been performed within the frames of the Baltic Green Belt project. The hindrances and suggestions for sustainable development are analyzed and described by author in geographic comparative context, distinguishing the natural and social economic differentiation of Lithuanian coastal strip, indicating the suggestions towards sustainability.

The aim of research - to analyze the causes of hindrances for coastal strip's development and to maintain geographic suggestions for implementation of sustainability for Lithuanian coast.

There were used retrospective, comparative, statistical-mathematical, GIS and mapping, descriptive methods of research as well.

The data in tables are calculated and re-calculated by author using different sources of previous studies, projects, reports, web-portals, satellite images. The article contains the analysis of geographic profile, degree of exploitation, existence of spatial planning measures and suggestions for sustainable coastal strip development.

\footnotetext{
Eduardas Spiriajevas - Klaipeda University, Faculty of Social Sciences, Head of Department of Human Geography, Assoc. Prof. Dr., scientific interests: Social economic problems of border regions and their development, Impact of border as a barrier for cooperation of South-East Baltic regions, Impact of tourism for development of border regions and regional disparities of tourism development, Economic geographic differentiation of industries, Geographic problems of cultural heritage protection.

E-mail: geostudijos@gmail.com

Tel.: + 37046398674
} 


\section{Geographic profile of Lithuania's coastline and coastal region}

The Baltic coast of Lithuania extends to $91.6 \mathrm{~km}$, and it is one of the shortest national coastlines in Europe. The northern part ( $46 \mathrm{~km}$ ) of the Lithuanian Baltic coast belongs to three municipalities: Klaipeda city municipality, Klaipeda district municipality and Palanga municipality, and the southern part (45.6 km) belongs to Neringa municipality and Klaipeda city municipality as well.

Klaipeda is the third largest city with 167000 inhabitants (2011) and the city is Lithuania's major seaport. Palanga is the biggest seaside resort with 17600 inhabitants (2011). Neringa is an elite seaside resort with 3600 inhabitant (2011). Klaipeda district municipality is adjoining area like and its administrative center Gargždai with 16100 inhabitants is situated inland (18 km eastwards from Klaipeda city), but this municipality has territorial access to the Baltic sea and the Curonian lagoon as well. In the western part of Lithuania reside about 400000 inhabitants (13.3\% of total population), in the meantime, along the coast (up to $5 \mathrm{~km}$ in land) there live nearly to 210000 inhabitants (7\% of total population). According to economic activities there are about 10000 SMEs, the economy of the region generates nearly to $12 \%$ of Lithuania's GDP. The incomes from fishery industries generates nearly to $0.7 \%$ of Lithuania's GDP as well (2011). The region is rich with natural recreational resources and cultural heritage. The industries of tourism serve about 1000000 of national visitors and 500000 international visitors per year roughly. The most attractive sites are located on or nearby the Baltic coast: the Kuršiu nerija national park, the Pajūrio regional park, Klaipeda, Palanga, Šventoji.

The Lithuanian coastal strip belongs to the southeast Baltic region of graded coasts, which took their present shape during Pleistocene and Holocene. The morphological structure of the coast is rather simple. The southern half is formed by the Kuršiu nerija (the Curonian Spit), a narrow concave peninsula separating the Kuršių marios (the Curonian Lagoon) from the Baltic Sea. The Kuršių nerija is a sandy stretch of land extending 98 kilometers, half of which belongs to Lithuania, the other half to Russia. The width of the peninsula varies from $400 \mathrm{~m}$ to $3.8 \mathrm{~km}$.

Four different dynamic types of coasts could be distinguished along the Lithuanian Baltic coast:

1. Slight accretion prevails between Nida and Juodkrante. Shoreline is relatively stable there. The beach is relatively wide, covered by medium-sized sand grains with admixture of gravel. It is framed by the 6 to $8 \mathrm{~m}$ high artificial foredune. The foredune is covered by marram grass, sea rocket and other perennial grasses, while the dune blow-outs are overgrown mainly by willows. The foredune was artificially created in the 19th century in order to protect coastal villages from the devastating sand drift. It stretches along the entire Lithuanian Baltic coast except few places north of Klaipeda.

2. The coastal strip between Juodkrante and Melnrage is characterized by a relatively strong accretion. The average advance of the shoreline to the sea is up to $2 \mathrm{~m}$ there (except the places adjacent to the Seagate of the Klaipeda harbour). The beach is wide $(50-70 \mathrm{~m})$, covered by a wellsorted medium-sized sand. It is framed by a 12 to $14 \mathrm{~m}$ high artificial foredune. The nearshore is very shallow.

3. The coastal strip between Melnrage and Nemirseta is characterized by a moderate erosion and shoreline retreat up to $1 \mathrm{~m}$ annually. Glacial coastal scarps and bluffs prevail here covered with the sand of the Holocene Aeolian accumulation and forming coastal formations, which are unique for Lithuania.

The height of the coastal cliff near the Olando Kepure is up to $24.4 \mathrm{~m}$ at Karklè. The cliff is active, not covered by vegetation, with numerous traces of landslides and landslips, fallen trees and sliding bushes. The beach in the strip between Melnrage and Nemirseta is relatively narrow, 15-25 m width, covered by mixed sediments, where the gravel prevails with admixture of medium-sized sand, pebble and boulders. Therefore, this area is one of the most important spawning places for the Baltic herring. 
Table 1. Geographic data of Lithuania's coastline and coastal region

\begin{tabular}{|c|c|}
\hline $\begin{array}{l}\text { Length of national coastline } \\
\text { Continental (northern) } \\
\text { Share of coastal area in Lithuania } \\
\text { The Kuršiu nerija (southern) } \\
\text { Share of coastal area in Lithuania }\end{array}$ & $\begin{array}{l}91.6 \mathrm{~km} \\
46 \mathrm{~km} \\
50.2 \% \\
45.6 \mathrm{~km} \\
49.8 \%\end{array}$ \\
\hline $\begin{array}{l}\text { National coastal zone in total with: } \\
200 \mathrm{~m} \text { inland } \\
500 \mathrm{~m} \text { inland }\end{array}$ & $\begin{array}{l}18.2 \mathrm{~km}^{2} \\
45.3 \mathrm{~km}^{2}\end{array}$ \\
\hline $\begin{array}{l}\text { National parks } \\
\text { ThePajūrio regional park } \\
\text { Protected area in total } \\
\text { Protected area of territory } \\
\text { Protected area in the Baltic sea } \\
\text { Forested area } \\
\text { Length of protected coastline } \\
\text { Share of total national coastline } \\
\text { Settlements } \\
\text { Population } \\
\text { The Kuršiu nerija national park } \\
\text { Protected area in total } \\
\text { Protected area of territory } \\
\text { Protected area in the Baltic sea } \\
\text { Forested area } \\
\text { Protected area in the Kuršiu marios } \\
\text { Length of protected coastline } \\
\text { Share of total national coastline } \\
\text { Settlements } \\
\text { Population }\end{array}$ & $\begin{array}{l}5865 \text { ha } \\
2735 \text { ha } \\
3130 \text { ha } \\
30 \% \\
15 \mathrm{~km} \\
16.5 \% \\
\text { Karklè, Kalote, Nemirseta } \\
750 \\
26461 \text { ha } \\
9761 \text { ha } \\
12500 \text { ha } \\
75 \% \\
4200 \text { ha } \\
45.6 \text { km } \\
49.8 \% \\
\text { Nida, Juodkrante, Preila, Pervalka } \\
3500\end{array}$ \\
\hline $\begin{array}{l}\text { Municipalities } \\
\text { Klaipeda city municipality } \\
\text { Area }\left(\mathrm{km}^{2}\right) \\
\text { Population } \\
\text { Density of population } \\
\text { Adjoining settlements on the coast } \\
\text { Klaipeda district municipality }\end{array}$ & $\begin{array}{l}98 \mathrm{~km}^{2} \\
167000 \\
1704 \text { per km² } \\
\text { Melnragé, Giruliai }\end{array}$ \\
\hline $\begin{array}{l}\text { Area }\left(\mathrm{km}^{2}\right) \\
\text { Population } \\
\left.\text { Density of population (per } \mathrm{km}^{2}\right) \\
\text { Palanga urban municipality }\end{array}$ & $\begin{array}{l}1336 \mathrm{~km}^{2} \\
53000 \\
39.7 \mathrm{~km}^{2}\end{array}$ \\
\hline $\begin{array}{l}\text { Area } \\
\text { Population } \\
\text { Density of population } \\
\text { Settlements } \\
\text { Neringa municipality }\end{array}$ & $\begin{array}{l}79 \mathrm{~km}^{2} \\
17600 \\
222.8\left(\mathrm{~km}^{2}\right) \\
\text { Šventoji, Būtingè }\end{array}$ \\
\hline $\begin{array}{l}\text { Area } \\
\text { Population } \\
\text { Density of population }\left(\text { per } \mathrm{km}^{2}\right) \\
\text { Settlements }\end{array}$ & $\begin{array}{l}94.4 \mathrm{~km}^{2} \\
3600 \\
38.1 \text { per km² } \\
\text { Nida, Pervalka, Preila, Juodkrantė }\end{array}$ \\
\hline
\end{tabular}

Source: Elaborated by Spiriajevas, 2011.

4. North of Nemirseta the grading of the coast during the series of the Baltic Sea transgressions all through the Holocene created favorable conditions for sand accretion. The shoreline is relatively stable (except the places adjacent to the Palanga pier and Butinge waste-water discharge pipeline). The beach is relatively wide 
$(50-90 \mathrm{~m})$, covered by a well-sorted medium-sized sand. The beach is framed by the 3 to $6 \mathrm{~m}$ high artificial foredune. The foredune is covered by marram grass, sea rocket and other perennial grasses, while the dune blow-outs are overgrown mainly by willows. Therefore, this area is also among the most suitable spawning places for the Baltic herring. The major landmarks of this area are two parabolic dunes: the Birute hill and the Nagliai hill reaching 20 m altitude (Povilanskas, Urbis, 2004; Povilanskas, 2002; Dubra, Grecevičius, Dubra, 2011; Grigelis, 2000; Methods for Conflicts..., 2006; Schernewski et al., 2004; Žilinskas, 2005; 2008; 4th NATIONAL Report...2009).

\section{Degree of exploitation of the coastal strip}

The exploitation of the coastal strip is appropriate for industrial, fishing and recreational actions mostly. Most of them are concentrated on the northern part of coastline, i.e. from Klaipéda seaport up to Būtingè oil terminal close to Latvia, and both objects are considered as the main hot spots on Lithuanian coast. The rest of area remained unexploited intensively and some of them are under protection.

The starting places for local fishing enterprises are in Melnragè, Karklè, Nemirseta, Šventoji, Juodkrantè, Nida, but there are no proper jetties and their installations for fishing activities. The fishing boats are being kept on the beach or they are being transported inland and outland from various keeping places nearby the settlements.

The recreational exploitation is the following:

1. The northern part of coastal strip is in intensive recreational use, mainly by recreationist on the beach. During the summer season the biggest territorial congestion of recreationists is appropriate for Melnragé, Giruliai, Palanga and Šventoji, as well on the northern part of the Kuršių nerija so called Smiltyne, which territorially belongs to Klaipeda city municipality.

2. The coastal strip of Palanga resort is in intensive use. Especially, during the summer season, during one day the beaches of Palanga are being visited nearly to 180000 visitors per day.

3. More extensive use of recreational resources is appropriate for the Kuršių nerija. Relatively high ferry fares for cars transporting through the Kuršiu marios (approximately 12 Eur per car) and collections of ecological fees (approximately 8 Eur per car), makes the park more attractive for wealthy national and foreign visitors. The beaches of Smiltyne are very popular among the inhabitants of Klaipeda city; they are less crowded and distinguished for better quality of sand and cleaner water. The rest of coastal strip is under the law of protection, except fishing by quotas is permitted.

Hereby, in the law of Seaside Strip issued in 2002, there are noted that the building activities are not permitted closer than $100 \mathrm{~m}$ before the coastline of the Baltic Sea, and no closer than $50 \mathrm{~m}$ before the coastline of the Kuršių marios, except the buildings, installations devoted for infrastructural and public needs (piers, wavebrakers, harbours' needs and etc.). The action of exploitation for private housing is permitted only if there were old homesteads that need to be rejuvenated, restorated, and it is not permitted to increase the space of the homesteads in comparison to the previous ones.

According to the intensity of exploitation of private housing in coastal strip, there are performed ranking of settlements, indicating the change in number and in time. The change of rejuvenation intensity (in decreasing order) of private housing on Lithuanian coast (2005-2011) is the following:

- The northern part of coastal strip: Palanga, Šventoji, Melnrage, Giruliai, Karklè, Nemirseta;

- The southern part of coastal strip: Nida, Juodkrante, Pervalka, Preila, Smiltynè, Alksnynè.

Depicting rejuvenation intensity of private housing only $200 \mathrm{~m}$ inland from the Baltic Sea, the settlements of Šventoji and Karkle experienced the most intensive mentioned process. The use of coastal zone for private housing might be estimated only on expert level, because in Lithuania there is no trustworthy data. 


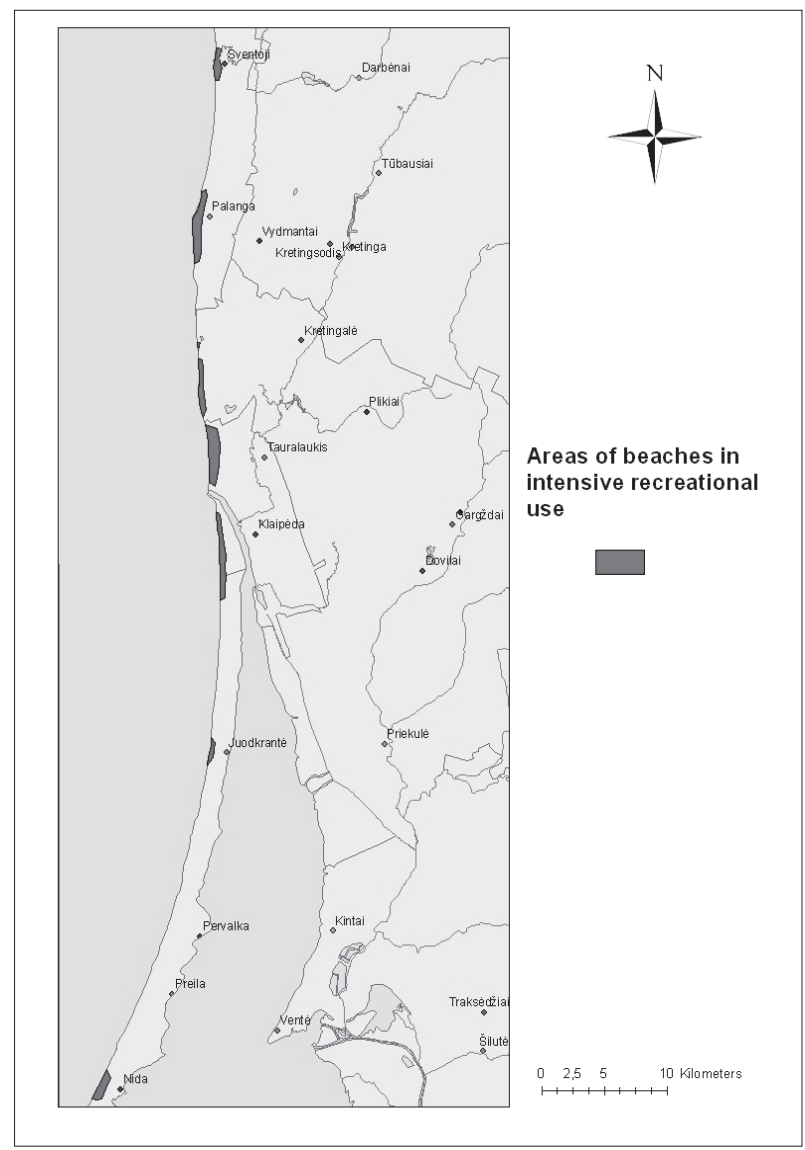

Figure 1. Areas of beaches in intensive use in Lithuania's coastal strip Source: Elaborated by Spiriajevas, 2011.

Nowadays, the exploitation is oriented to industrial reclamation of coastal strip, including the littoral zone. In general, coastal strip is not adjusted for the servicing of marine recreational needs. There is still the lack of piers, not sufficient infrastructure for sustained access to the sea (especially in the northern part). There is a lack of renting of marine recreational equipment and bicycle, marine recreational services for visitors, catering services, informational infrastructure on the sites, parking places, other services for public needs (public transport, drinking water sources). In the future, the small harbour installations are planned to build up in Karkle and Nemirseta. Where is permitted, the areas are urbanized intensively and in state owned forests the building of new additions is not permitted.

Estimating the exploitation of coastal strip according to mentioned activities, there are presented the following data:

Table 2. Data about the degree of exploitation of coastal strip $500 \mathrm{~m}$ inland

\begin{tabular}{|l|l|}
\hline Klaipėda Oil Terminal & 43,34 ha \\
\hline Būtingè Oil Terminal & 0,86 ha \\
\hline Small harbours installations & 0,30 ha \\
\hline $\begin{array}{l}\text { Beaches in intensive } \\
\text { recreational use }\end{array}$ & $\begin{array}{l}119,82 \text { ha } \\
\text { In continental part } 59,16 \text { ha } \\
\text { In the Curonian Spit } 60,66 \text { ha }\end{array}$ \\
\hline Recreational infrastructure & 8,77 ha \\
\hline
\end{tabular}




\begin{tabular}{|l|l|}
\hline $\begin{array}{l}\text { Natural areas under } \\
\text { protection }\end{array}$ & $\begin{array}{l}2750 \text { ha } \\
\text { The Pajūrio regional park } \\
750 \text { ha } \\
\text { The Kuršių nerija national park 2000 ha }\end{array}$ \\
\hline Hydrotechnical installations & 1,5 ha \\
\hline Settlements & 151,37 ha \\
\hline $\begin{array}{l}\text { Other former military } \\
\text { buildings }\end{array}$ & 4 ha \\
\hline
\end{tabular}

Source: Elaborated by Spiriajevas, 2011.

In Lithuania there were no any small harbours' installations and private pier, and until now they aren't built. There are no any proper conditions for amateur fishermen activities. Palanga resort does not provide any marine recreational services for visitors and the Palanga Bridge could have provide the function as the pier as well, but there are no entrepreneurs wishing to undertake the services of marine recreation.

Concerning the distribution of protected area on Lithuanian coast, the network of protected areas is rather dense. The Kuršiu nerijos national park is involved in the heritage list of UNESCO. The Nemunas Delta regional park (by the Kuršiu marios) is involved in the group of wetlands that are protected by RAMSAR convention. All the national parks and reserves including their aquatories in the Baltic Sea and the Kuršiu marios included in the NATURA 2000 for protection of birds' species. Relatively, all the protected areas are devoted for protection of natural habitations within NATURA 2000 (exept the central and southern aquatories of the Kuršiu nerija national park).

Concerning the dredging actions, the most active processes of dredging are appropriate within the Klaipedda strait for operation of shipping, and in the proximity to the Bütinge oil terminal for operation of oil transportation. The both places are considered as the hot spots on Lithuanian coast.

The aquatory close to the Būtinge oil terminal is not under protection, but the northern part of the Kuršiu nerija is close to the Klaipeda strait is under protection of NATURA 2000.

Concerning the national legal system and spatial planning system both have procedures that guarantee the biodiversity, recreational and ecosystem values will be protected and takes seriously into account at all new proposals for exploitation in the coastal strip (0-200 $\mathrm{m}$ and up to landwards and in the same area $(0-500 \mathrm{~m})$ seawards. The strong mandatory rules for biological and ecological inventories studied.

Generally, the system of legislation concerning environmental protection in Lithuania is developed rather sufficient. In some cases the laws are even to strict to perform any economic activities in protected areas. Otherwise, most of the laws are being kept with no fully involved regulations, because the capabilities of state authorities are not sufficient to keep all the validations or to supervise them in the reality. One of the reasons is that the competencies of public administration are still remaining too weak and besides they are facing the contradiction between public and private interests.

The following findings considered concerning the interaction between exploitation and protection of coastal strip:

- In the aquatory of the Pajūrio regional park there is being protected boulders' sites between Karkle and Giruliai, wherein is the main spawning place of fish communes;

- Lithuanian coastal strip is important for birds' wintering (on Lithuanian coast for wintering there are being gathered about $10 \%$ of the total population of Siberian eider ducks);

- The main fishing areas in intensive use are in the distance of $2 \mathrm{~km}$ seawards from the coastline, in the meantime extensive fishing areas are in the distance of $500 \mathrm{~m}$ seawards from the coastline;

- Amount of fishermen is decreasing annually, thus the scopes of traditional fishing is decreasing as well. 


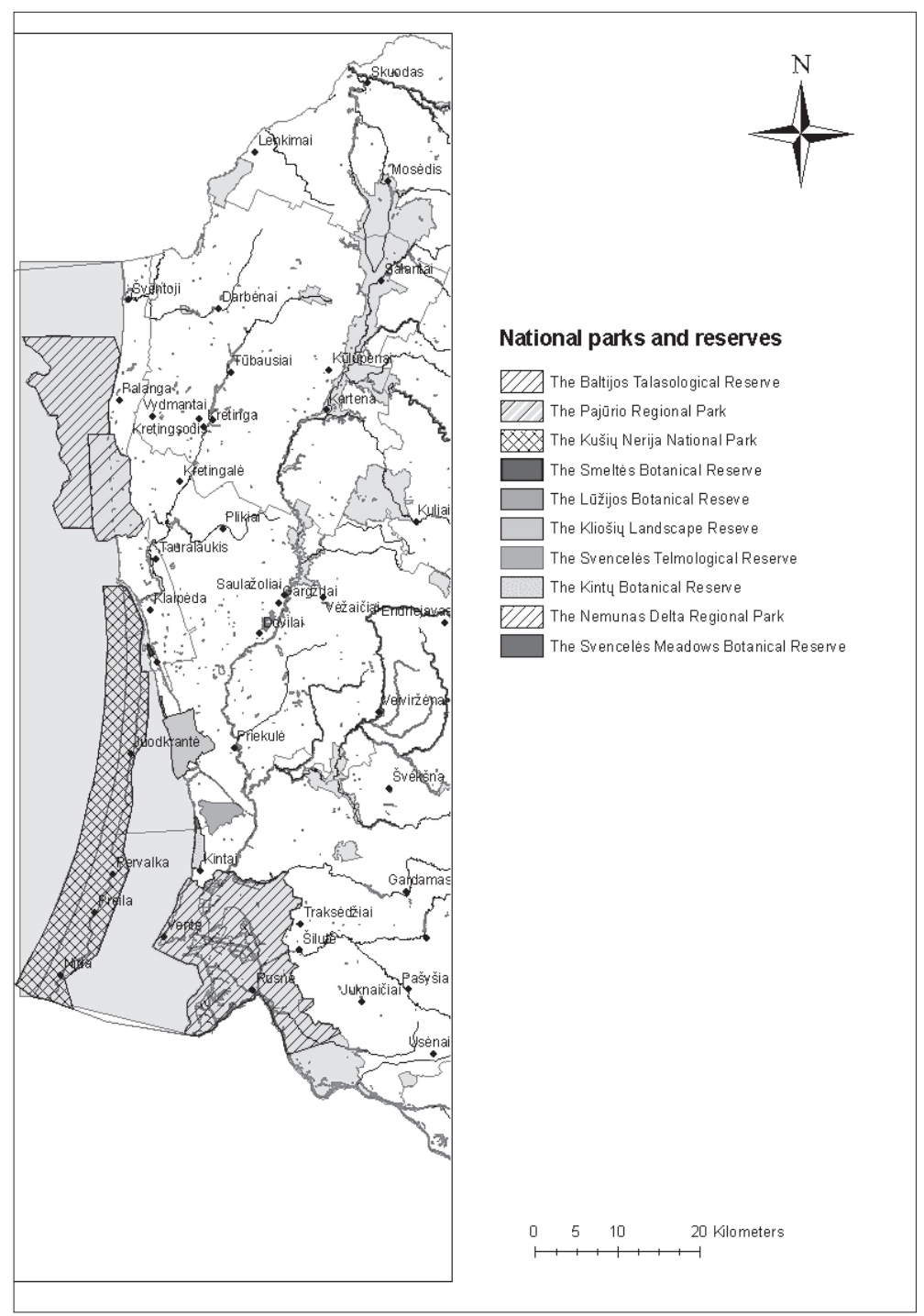

Figure 2. The National parks and reserves in Lithuania's coastal strip Source: Elaborated by Spiriajevas, 2011.

The coastal strip of Lithuania is protected rather sufficient by legislation and by practical solutions as well. The efficiency of practical solutions depends on the responsibilities and competencies of the administrations of national parks. The main goal of the Programme for the Lithuanian Coastal Strip Management (Lithuanian continental coast of the Baltic Sea) is to save natural complexes of the coastline and create optimal conditions for the sustainable use of natural resources.

According to carried out interview of the Pajūris regional park administration ( $8^{\text {th }}$ November, 2011), concerning the plans for coastal development, there were determined the following findings:

- Legislative basis for coastal strip protection is sufficient. The coastline is under protections of Coastal Strip Law (2002). The coastal strip is a state owned land, where any possible economic activity is being strictly regulated;

- For the protections of coastal strip there are being adjusted different laws and the documents of territorial planning;

- Insufficient functional use of public and private buildings and their architectural expression is not strictly determined by laws and general plans;

- Coastal strip is developing for recreational purposes, new additions performs the function of second homes (in Nida, Juodkrantè, Giruliai, Palanga, Šventoji); 
- In the areas that are outside the national parks, the new additions have no appropriate architectural style (in the surrounding of 2-3 homesteads there are built the blocks of flats, which do not match the harmony of coastal landscape itself.

- Architects ignore different measures of laws and regulations concerning protection of coastal strip as an integrated system;

- Environmental protection is sufficiently regulated by laws. The core problem is undeveloped centralized sewage system in villages and blocks of dwellings. Most of them have installed autonomous sewage equipments.

- The capacities of public infrastructure are to low to serve the needs of locals.

- The Law on Coastal Strip protection occurs the area about $100 \mathrm{~m}$ inland, that is state owned, but some exceptions exist in Karkle (one dwelling house is built almost on the dune, and due to coastal erosion the local cementary is situated to close to the sea. Also, conflicts of illegal new additions in the Kuršiu nerija near the coast of the Kuršiu marios in Preila and Pervalka).

- Possible negative impact on coastal protection can make planning development of the ports in Melnragè and Šventoji;

- The status of deep water port and its perspective still remains undetermined. Better solution for place in Būtingè.

- Priority has to be given for infrastructural projects, than for construction projects.

- Better solution to leave territories without intervention until the infrastructure will be developed. Development of coastal strip has to be in parallel to development of infrastructure.

- Concerning the protection of biodiversity, the suggested way of urbanization has to be in dot-like manner, i.e. some places are developed, and in the meantime some of them have to be remaining pristine. Between the dots of urbanization there has to be distinguished space for extensive exploitation.

- Along the Lithuanian coastal strip there are two national parks that keep the balance between urban development, exploitation of resources and environmental protection.

- The network of protected areas tries to sustain exploitation of territories (including their aquatories);

- Rather intensive fishing and to small fishes' population. There are legislative regulations concerning fishing periods, the use of nets and the size of "eyes" in the nets.

In the Pajūrio regional park there are situated nature reserve of Placio lake, Olando Kepurè, Nemirseta and Šaipiai landscape, Karklè botanical-zoological, Karklè talasological (in the aquatory) and Karklè ethnocultural reserves, recreational and agro territories.

In the Kuršių nerija national park there are situated Naglių and Gobšto nature reserves, Lapnugario, Juodkrantės, Karvaičių, Parnidžio landscape reserves as well.

Both national protected areas (including their aquatories as well) are involved in Natura 2000. Since 2011 there were approved the special plan for development of continental part of coastal strip.

\section{Existence of spatial planning in the coastal zone}

Questions of spatial planning in the coastal strip of Lithuania always have been on a high level of importance. As it is known, during the Soviet period the Neringa peninsula had the status of semi-closed area. The visiting was allowed only having issued permission for visiting of relatives, friends. The recreational facilities were limited. The sites like Juodkrante, Nida used to be to accept the visitors only with invitations, which have been planned at least 6 months in advance. Thus, the amount of visitors to peninsula was controlled rather strong. Otherwise, Neringa as well as other places like Karklè, Nemirseta and Šventoji had the status of border areas that were watching and controlling by the Soviet regime, and these areas were semi-closed for visitors as well. Nevertheless, the spatial planning existed in terms of planned economy. For the needs of local inhabitants there were devoted the following places like Smiltyne (beaches), Melnrage (housing and beaches), Giruliai (beaches, campsites for teenagers (so called pioneers) (in Giruliai was established the 
sanatorium for kids and teenagers for heeling of tuberculosis). Palanga resort was very popular among all the inhabitants of Lithuania, especially during the summer time. At that time Palanga played an important role performing the functions of wellness, heeling, there were operated sanatoriums, pool with warmed-up sea water.

Since Lithuania regained the independence, the coastal areas faced a plenty of conflicts in the process of regaining the land, houses as a property that was owned before the $2^{\text {nd }}$ World war. The conflicts between public and private interests in coastal region always have been the question of high importance on national level. The tendencies of market economy put aspects of chaotic territorial development, i.e. regained land, houses as a private property attracted new inhabitants (owners) that had no previous experience how to deal their lifestyle in coastal zone, in use of resources. The remaining of Soviet public infrastructure lost their physical shape and value. The new additions of public infrastructure started to appear at once.

Recently, the natural process of market makes permanent penetration for intensification of urbanized process that leads towards congestion of urban structures in areas where that process is possible according to national relevant laws.

In the entire coastal area Palanga and Klaipeda, both are two separate places with dot-like principle of urban development around their axes. The rest of the areas are appropriate for extensive exploitation. The Kuršiu nerija has only $2 \%$ of urbanized territory and there is kept the balance between urban development and environmental protection, balance between functional balance and traditional architecture. In the general plan of Lithuania the coastal strip is distinguished as an important areal for sustainable development. For the continental part of coastal strip prepared integrated plan for exploitation, environmental protection, formation directions of landscapes and other measures for development.

Particularly, every municipality has confirmed general and detail plans of their areas. The general plan of coastal strip is a legal basis towards territorial sustainability, i.e. planning of new territorial projects, strategic documents, allocation of financial support of EU funding, adjusting public and private interests, etc.

\section{Suggestions for sustainable coastal strip development}

\section{The core problem}

The coast and coastal strip both have still rather weak approach as an integrated territorial system. Even the perception of coastal region faces the lack of public and institutional approach in public administration. Thus, the infrastructure is being developed apart from integrated approach of coastal zone management. Territorial planning decision makers face the contradiction between public and private interests, even though there are confirmed general plans and detail plans, the separate private interests are prevailing especially in unprotected areas of coastal strip (Melnragè, Giruliai, Šventoji). Mandatory specific planning for coastal zone management has to be the legal measure for sustainable development. Thus, the approach towards ICZM (Integrated coastal zone management) has to be integrated.

The suggestion for improvement towards sustainability

The elaboration and legislative approval of the scheme within the action of public administration on municipal and national levels will make the implementations of ICZM principles more transparent. The duties of responsibilities have to be shared and clearly defined within institutions on municipal and national levels.

The core problem

The process of development of settlements also has no clear vision, because the developing settlements, villages are overtaking the urban culture and life style, thus they are not preserving rural culture, but becoming a part of cities.

The suggestion for improvement towards sustainability

For urban planning in coastal areas has to be elaborated clear vision in perception of coastal landscape related to traditional and re-establishing historical architectural style with strict legislative regulations. The priority for public needs has to be over private interests. 


\section{The core problem}

In the coastal areas, traditional businesses have been fishery and cattle-breeding. Now the cattle-breeding is almost disappeared and does not play the role of incomes for locals. Traditional fishery business is becoming weak due to the lack of proper installations, state support, quotas for fishing, almost lost fishing habits. Also, the self-cost of traditional fishing became too high and unprofitable.

The suggestion for improvement towards sustainability

The former plots for cattle-breeding have to be kept using available methods of sustainability, i.e. introducing sheeps and goats as alternatives.

The government has to recognize traditional fishing on the same level as traditional handicrafts that are recognized as alternative economic activities in rural areas. In the meantime these activities are eligible for state support as heritage.

The core problem

The plots for agriculture are not in use by farmers. Just some of them are in extensive use. The agriculture as an economic activity lost its value and its importance as the source of incomes. Especialy, in the northern part around Nemirseta, Karkle there are some gazing plots for sheeps, goats and horses. This action was introduced by different EU environmental projects for prevention of gazing plots against the processes of grass over. In other places are prevailing the meadows covered by chickweeds. The locals are not undertaking the farming activities due to the need to use the areas for second homes. Therefore, the state has to take care of natural trim.

The suggestion for improvement towards sustainability

The private areas in the coastal territories that are not well kept, there have to be implemented legislative measures with defining more transparent responsibilities of land owners.

The experience for implementation of principles of IZCM has to share noting transparent outcomes of the actions. There has to be elaborated monitoring system with description of good and bad examples and shared experience. There has to be generated the joint master plan for monitoring and transparent methodology for assessment of risen up changes and their peculiarities not only in nature, but in socio-economic processes as well. The suggestion to prepare the study about desolate buildings and objects of infrastructure in former borderlands and it must have a clear vision for readjusting of these constructions for recreational and other public needs (in general, along the entire coastal strip of Lithuania, there are counted 55 desolate ownerless buildings). There is suggested to elaborate thematic atlas about different processes of coastal development and comparative descriptions with cartographic representations.

\section{Conclusions}

The bad examples on sustainable development and exploitation of the coastal strip are distinguished into the following types:

- Institutional - the lack of inter-institutional share of responsibilities that is a cause of the problems related to ICZM.

- Projects related - the plans to build up the deep water harbour in Melnrage that is a cause of broking up of sustainable development of coastal strip.

- Shortage of financial issues - due to shortage of financial issues, the local authorities are able to execute the fixings of dunes only in critical spots. The self-cost for the reinforcements of the dunes on the coastal strip is for about 15000 EUR per $1 \mathrm{~km}$ of coastline.

- Private housing - it is appropriate for sites where were re-established the rights for the private property. There were issued the permits for reconstruction of the buildings and in many cases the process of reconstruction did not match the peculiarities of coastal landscape and morphological processes. In some places after the rejuvenation of buildings and enlargements of their yards, there were closed public accesses to the beaches. Some of accesses became narrowed. Thus, ignoring the public interests, some plots of them became "semi-private", what do not match the national legislation. 
The good examples on sustainable development and exploitation of the coastal strip are distinguished into the following types:

- Legislative - the basis for environmental protection is rather sufficient and diversified. Lithuania had ratified and accepted the majority of international conventions and on the base of them elaborated the additions for national legislation of environmental protection for the coastal zone.

- Institutional - the role is different according to the capabilities of public administrations, but the administrations of the natural parks are in a very principle in dealing with many solutions concerning the protection of coastal zone, and they have a strict legislative approach towards implementation of any solutions.

- Projects related - the actions towards protection and development of the coastal areas are being implemented by different institutions (municipalities, agencies of environmental protection, institutions of research and higher education, local communities and NGO's as well. During the period of 2003-2011 on the continental part of coastal zone there were implemented the projects related to tourism system development, preservation of flora and fauna, implementation the principles of sustainable rural development and land use, project related to artificial nourishment of the aquatories and beaches by sand, reinforcement of dunes using geotextile and natural materials, development of recreational infrastructure using natural materials, and other educational projects.

- NGOs related - the actions supports the dissemination of information about the hot spots in the coastal zone, represents the societal interests in protection of public needs in the parts of coastal zone that devoted for industrial use. One of the most well know NGO in western Lithuania related to protection of Lithuanian coastal zone is ecological club „Žvejone““ established in Klaipéda and is in intensive action since 1993 for green movements.

\section{References}

Dubra, V., Grecevičius, P., Dubra, J. (2011). Current Changes of Sandy Seashore of Lithuania within the Impact of Natural and Anthropogenic Processes. Littoral 2010, 06006.

Grigelis, A. (2000). Implications of Accelerated Sea Level Rise (ASRL) for Lithuania. Proceedings of SURVAS expert workshop on European vulnerability and adaptation to impacts of accelerated Sea-Level Rise (ASLR). Hamburg, Germany, 19-21 June, 2000.

Methods for Conflicts Resolutions at Lithuanian Coastal Zone. Project COASTMAN. (2006).

Povilanskas, R. (2002). EUROSION Case study. Klaipeda: EUCC Baltic Office.

Povilanskas, R., Urbis, A. (2004). National ICZM strategy and initiatives in Lithuania.

Schernewski, G., Löser, N. (eds.) (2004). Managing the Baltic Sea. Coastline Reports, No. 2, p. 9-15.

Žilinskas, G. (2005). Trends in dynamic processes along the Lithuanian Baltic coast. Acta Zoologica Lituanica, Vol. 15, No. 2.

Žilinskas, G. (2008). Distinguishing priority sectors for the Lithuanian Baltic Sea coastal management. Baltica, Vilnius, Vol. 21 (1-2), p. 85-94.

4th NATIONAL Report of the Republic of Lithuania to the Convention on Biological Diversity. The Ministry of the Environment of the Republic of Lithuania. (2009). 


\section{LIETUVOS PAJÜRIO JUOSTOS DARNIOS PLETROS KLIUVINIAI IR PASI ŨLYMAI, KAIP JŲ IŠVENGTI}

EDUARDAS SPIRIAJEVAS

Klaipėdos universitetas (Lietuva)

\section{Santrauka}

Lietuvos Baltijos jūros kranto ilgis yra 91,6 km - vienas trumpiausių tarp Europos valstybių. Šalies pajūrio juosta (kranto zona) labiausiai naudojama pramonès poreikiams, žvejybai, rekreacijai. Daugelis šių ekonominių veiklų sutelktos šiaurinèje pajūrio juostos dalyje, t. y. nuo Klaipèdos uosto iki Būtingès naftos terminalo, šalia Latvijos pasienio. Šie abu pramonès objektai ir jų teritoriniai kompleksai yra pagrindiniai ekologinès rizikos skleidejai Lietuvos pajūryje. Kitoms pajūrio teritorijoms būdinga ekstensyvi ekonominèūkinè plètra.

Iš esmès Lietuvos pajūrio juosta nepritaikyta jūrinei rekreacijai plètoti, trūksta prieplaukų, sutvarkytos viešosios infrastruktūros ir priejjimų prie jūros (ypač šiaurinėje dalyje), taip pat jūrinès rekreacijos, dviračių nuomos ir maitinimo paslaugų, informacijos infrastruktūros lankomose vietovėse, kitų viešujų paslaugų (viešojo transporto, irrengtu geriamojo vandens šaltinių, higienos įrenginių).

Rinkos sąlygos ir dèsniai skatina urbanistinių procesų skverbimąsi ì pajūrio teritorijas, dèl ko didèja urbanistinių struktūrų koncentracija, todèl pati pakrante ir pajūrio juosta tampa problemiška teritorine sistema. Net šalies viešojo administravimo sistemoje pastebima pakrančiı regiono, pakrančiu teritorijos, kranto zonos, pajūrio juostos sąvokų tapatybès problema.

Remiantis atlikto tyrimo rezultatais, nustatyti gerosios ir blogosios praktikos pavyzdžiai, susiję su pajūrio juostos ūkiniu naudojimu. Išskirti 4 blogosios praktikos pavyzdžių tipai, susiję su institucijų veikla, stambios infrastruktūros investicijų projektų igyvendinimu, finansinių išteklių trūkumu, privačios nuosavybès teisèmis. Išskirti ir 4 gerosios praktikos pavyzdžių tipai, susiję su įstatyminės bazès pakankamumu, institucijų veikla, investicinių projektų igyvendinimu, nevyriausybinių organizacijų veikla.

Svarbiausi pasiūlymai dèl darnios plètros apima siūlymus sukurti pajūrio juostos stebėsenos sistemą, kur būtų kaupiami gerosios ir blogosios praktikos faktai, susiję su pajūrio juosto ūkiniu naudojimu. Siūloma sudaryti ir temini atlasa, kuris vaizduotų skirtingus pajūrio juostos plètros procesus, tai sudarytų sąlygas atlikti palyginamają analizę su kartografinio atvaizdavimo priemonèmis.

PAGRINDINIAI ŽODŽIAI: darni plètra, Lietuva, pajūrio juosta (zona).

JEL KODAI: Q01, Q20, Q56, R11, Y10, Y91. 